\title{
AGENTIC POWER OF THE SEA IN JOHN MILLINGTON SYNGE'S RIDERS TO THE SEA ${ }^{1}$
}

\author{
Kübra VURAL ${ }^{2}$
}

\begin{abstract}
One-act play of John Millington Synge (1871-1909) Riders to the Sea (1904) is about the life in the Aran Islands, power of nature and death. While the life endowed with the sea determines the fate of Irish islanders, their dependence on the water surrounding the Aran Islands brings death, too. The sea both provides life and causes death in the play. However, agency of the sea is not just bound to this dualistic nature in Synge's work. The vision of the mother Maurya about the deaths of her two sons, Michael and Bartley, upon the sea evidences that agentic power of the water is not only affiliated with its ontological presence, but also its epistemological capacity which is about the narrative ability of matter. This paper sets out to scrutinise agency of the sea in Synge's Riders to the Sea in terms of material ecocriticism and new materialisms.
\end{abstract}

Keywords: Material ecocriticism, new materialisms, Irish drama, John Millington Synge

Vural, Kübra. "Agentic Power of the Sea in John Millington Synge's Riders to the Sea". idil 6.35 (2017): 1903-1913.

Vural, K. "Agentic Power of the Sea in John Millington Synge's Riders to the Sea" (2017). idil, 6 (35), s.1903-1913.

\footnotetext{
${ }^{1}$ A version of this paper was presented in "Ireland and Ecocriticsm: An Interdisciplinary Conference" at University College Cork in June 2014.

${ }^{2}$ Araştırma Görevlisi, Hacettepe Üniversitesi, Edebiyat Fakültesi, İngiliz Dili ve Edebiyatı Bölümü, vural.kubra(at)gmail.com
} 


\title{
JOHN MILLINGTON SYNGE'IN DENIZE GIDEN ATLILAR ADLI OYUNUNDA DENIZIN EYLETICI GÜCÜ
}

\author{
öz
}

John Millington Synge'in (1871-1909) Denize Giden Atllar (1904) adlı tek perdelik oyunu Aran Adalarındaki hayatı, doğanın gücünü ve ölümü anlatır. Denize dayalı yaşam tarzı İrlandalı adalı insanların hayatını belirlerken, adaları çevreleyen suya olan bağımlılık oyunda ölümü de beraberinde getirir. Deniz hem hayat sağlar hem de ölüme sebep olur. Ancak deniz etkeni Synge'in oyununda sadece bu türden bir ikiliğe bağlı değildir. Oyundaki anne karakter Maurya'nın oğulları Michael ve Bartley'nin ölümünü denizde suya bakarken görmesi suyun gücünün sadece ontolojik görünüşüne değil, aynı zamanda maddenin hikâye anlatması bağlamında epistemolojik yönüyle de ilişskili olduğunu gösterir. Bu çalışmanın amacı Synge'in Denize Giden Atlılar adlı oyununda deniz etkenini maddesel ekoeleştiri ve yeni maddecilik bağlamında incelemektir.

Anahtar Kelimeler: Maddesel ekoeleştiri, yeni maddecilik, İrlanda tiyatrosu, John Millington Synge 


\section{INTRODUCTION}

J. M. Synge's one-act play Riders to the Sea is among the early plays of the national theatre of Ireland, the Abbey Theatre. Founded in 1904 with the aim of representing Irish characters by the Irish playwrights on stage, the Abbey Theatre hosted works of Irish dramatists who thoroughly returned to the Irish myths, stories and their national troubles as a source of inspiration. Synge, as his contemporaries at the time, centred his play on the life of Irish peasants in the Aran Islands. His work dominated by female figures takes place in a cottage of the Aran Islands, and its plot structure, albeit a simple one, is enriched by the playwright's effective use of language and symbols. As the life of those peasants is threatened by certain harsh conditions and death in the sea, the play is enmeshed with a tragic tone. Synge records the desperate situation of the peasants in a land where "one is enforced to believe in a sympathy between man and nature" (Synge, 1992: 37) in that the sea dominates their lives as a powerful force.

Riders to the Sea opens with Cathleen and Nora's anxious waiting for the news about their lost brother Michael's fate in the sea upon which Maurya's only living son Bartley decides to go to the sea. After Bartley's leaving his family, the tension of the play rises with Maurya's vision that she claims to have seen upon the sea about the deaths of her two sons. As her vision comes true as reflected, the play ends with her lamentation and submission to the fate. Therefore, the play instantiates, in Synge's (1992) own words, "the glory and power of the waves" (91) through creative and destructive dynamics of water. In their search for life in the sea to feed themselves, the islanders are faced with a tragic end. Yet agency of the sea is not only limited with its dualistic nature as a life-giver and life-taker, but this power can also be extended to its narrative capability as revealed in Maurya's vision. This paper, therefore, aims to pinpoint agency of the sea in the analysis of Synge's play with a particular emphasis on its onto-epistemological dimension in the framework of material ecocriticism and new materialisms.

\section{AGENCY OF MATTER}

The main aim of this paper is to offer a text-based analysis through which ecocritical perspective, namely material ecocriticism and new materialisms, is tracked. In this light, theoretical background of ecocriticism is initially charted, and the analysis of Synge's play is later detailed in line with agency of the sea within the discourse of material ecocriticism. Therefore, it is necessary at this point to dissect the main points of ecocritical framework. Ecocriticism is a critical study of the relationship between human and nonhuman beings in stark contrast to anthropocentric 
world view which grants a central position for human beings in the universe. With its deconstruction of the hierarchy between nature/culture and human/nonhuman beings, ecocriticism has turned into an interdisciplinary field of study considering that the discussion of a wide range of movements such as feminism, postcolonialism, materiality, posthumanism and animal studies heads for new dimensions. Material ecocriticism is a branch of "rhizomatic" (Oppermann, 2010: 17-21) ecocritical studies that particularly focuses on matter's agentic capacities with respect to the connection between human and nonhuman beings. It precisely challenges conventional material and discursive practices in that material relations are amended in terms of agency and narrativity. Iovino and Oppermann (2012b) argue that "the new materialisms rethink ontology, epistemology, and ethics-being, knowing, and acting” (450), and material ecocriticism, accordingly, is "an introductory map of th[is] new paradigm" (Ioviono and Oppermann, 2012a: 75). That is to say, new materialisms and material ecocriticism are complementary fields, asserting the idea that matter has agentic power and vitality rather than a static position.

The framework of new materialisms suggests a radical pattern for the concept of matter regarding the claim that all bodies involve in material and discursive practices. Matter, therefore, exists in relation to other beings through a vibrant network. The theorist Jane Bennett (2008) asserts that "vibrant matter is not the raw material for the creative activity of humans or God. It is my body, but also the bodies of Baltimore litter, Prometheus's chains, and Darwin's worms, as well as the notquite-bodies of electricity, ingested food, and stem cells" (xii). All bodies interdependently co-exist together in a great network in which "bodies are not selfcontained units; all are permeable" (Alaimo, 2010: 135). This accessibility of matter indicates a specific connection among all bodies as Karen Barad (2007) also states that "[b]odies do not simply take their places in the world. They are not simply situated in, or located in, particular environments. Rather, 'environments' and 'bodies' are intra-actively co-constituted" (170). Barad's concept of intra-action refers to the connection among beings that comes from within, and this creates agentic power for matter. Barad (2007) argues that

agency is a matter of intra-acting; it is an enactment, not something that
someone or something has. [...] Agency is 'doing' or 'being' in its intra-
activity. [...] Agency is about changing possibilities of change entailed in
reconfiguring material-discursive apparatuses of bodily production,
including the boundary articulations and exclusions that are marked by
those practices in the enactment of a casual structure. (178)

As can be observed, agentic power enables matter to involve in a strong web of active connection. Barad (2007) further explains this connection in her term "agential realism" which means "an understanding of the nature of the relationship between 
discursive practices and material phenomena, an accounting of 'nonhuman' as well as 'human' forms of agency, and an understanding of the precise casual nature of productive practices that takes account of the fullness of matter's implication in its ongoing historicity" (811). Therefore, it should be noted that this type of agency is not only limited to material dimension, but also includes discursive formations. This is directly related to the narrative ability of matter, and material ecocriticism particularly deals with this aspect of matter. Oppermann (2013) upholds that

[m] aterial ecocriticism is the study of the expressive dynamics of nature's constituents, or narrative agencies of storied matter at every scale of being in their mutual entanglements. It seeks to explore the narrative dimension of the material world in terms of the stories embodied in material formations. The phrase 'narrative agency' means that we are surrounded by stories, which are not limited to historical narratives, archaeological and architectural signs, cultural and literary texts. There are also geological, biological, and cosmic stories that compel us to envision the physical world as storied matter teeming with countless narrative agencies that infiltrate every imaginable space and make the world intelligible. (57)

To put it differently, matter involves in discursive practices on the grounds that it produces meaning and tells a story with its agentic capacity as a text. Therefore, matter in its material and discursive realms can be identified with its own stories and histories. Iovino and Opperman (2012a) elaborate on this idea as follows:

\footnotetext{
The agency of matter, the interplay between the human and the nonhuman in a field of distributed effectuality and of inbuilt materialdiscursive dynamics, are concepts that influence deeply the ideas of narrativity and text. If matter is agentic, and capable of producing its own meanings, every material configuration, from bodies to their contexts of living, is 'telling,' and therefore can be the object of a critical analysis aimed at discovering its stories, its material and discursive interplays. [...] [This] focuses on matter's 'narrative' power of creating configurations of meanings and substances, which enter with human lives into a field of co-emerging interactions. In this [...] case, matter itself becomes a text where dynamics of 'diffuse' agency and non-linear casuality are inscribed and produced. (79-80)
}

That is to say, matter involves in an onto-epistemological realm owing to its intraction between other beings and its capacity to produce stories and meanings. This novel idea enables critics to focus on new perspectives in different texts where matter is observed to have an active role in the course of narrations. 


\title{
3.AGENCY OF THE SEA IN SYNGE'S PLAY
}

Synge's Riders to the Sea illustrates agentic power of "a rough and perilous sea" (Synge, 1992: 146), and the playwright makes use of his observations that he specifically refers in his book entitled The Aran Islands (1906). In this book, Mattar (2004) claims, Synge dwells on the islanders' oneness with nature (142). Oona Frawley (2009), likewise, states that

\begin{abstract}
Aran provided first-hand experience of the sea's ruthlessness and the constant negotiation with weather that curagh-travel demanded. Synge (1992) repeatedly notes the threat of drowning in The Aran Islands, and variously experiences exhilaration, terror and profound dejection - all aspects of the sublime - in the face of churning sea. (17)
\end{abstract}

In other words, Synge's observations about the vigorous sea and the ways it shapes lives of the islanders are mirrored in Riders to the Sea as "a reconciliation between the imaginative character and the [real] community" (Armstrong, 1964: 10). The play, therefore, embodies important place of the sea and its agentic force for those people.

The islanders' dependence on the sea is initially portrayed through the simple setting of the play: a "cottage kitchen, with nets, oil-skins, spinning-wheel, some new boards standing by the wall, etc." (Synge, 1941: 175). These simple objects of the peasant life are actually Synge's "primary means of making at least one aspect of the sea palpable and concrete on the stage - the sea as the source of livelihood for the islanders" (Durbach, 1971: 366). The objects symbolically and implicitly stand out to represent peasants' tightly-knitted life with the sea. Yet their connection with the surrounding water does not always help them survive; instead, it brings a tragic end to their lives as in the case of Maurya's family. The play illustrates that this tragedy lies in the death of men by drowning, and women are left behind to suffer and survive alone. As a case in point, when Bartley, Maurya's son, decides to go to the sea, the mother voices her worry, asking: "What way will I and the girls with me, and I an old woman looking for the grave?" (Synge, 1941: 179). However, he does not obey her mother, and his visit to the sea brings his own death. Losing the last man of her family, Maurya describes the terrible fact of their lives: "I've had a husband, and a husband's father, and six sons in this house - six fine men, though it was a hard birth I had with every one of them and they coming to the world - and some of them were found and some of them were not found, but they're gone now the lot of them ..." (Synge, 1941: 186). Although they depend on the sea for survival, their attempts in the sea end with death, and male figures appear to sacrifice their lives in this way. Durbach (1971) argues that "[a]11 men are riders to the same unappeasable sea" (371), and their riding turns into a path to their death. While men dies, "women endure, 
Maurya, spokeswoman for all three, justifies those deaths and acquiesces in them" (Benson, 1982: 64). More than this, the sea in Synge's work, Fermor (1967) claims, "fill[s] the minds of the characters as to shape their actions, moods and fates" (164), and it becomes "the protagonist, the main actor" (Fermor, 1967: 169) with its dualistic nature, "function[ing] as both the provider for the family and as its potential destroyer" (O'Neill, 2010: 36). In this regard, the presence of the sea in the play corresponds to its symbolic meanings as "a symbol of the dynamism of life [and] an image simultaneously of death and of life" ("Sea"). This duality is recognised by Maurya in that she indicates destruction of the sea, saying that "for when a man is nine days in the sea, and the wind blowing, it's hard set his own mother would be to say what man was it" (Synge, 1941: 187). The empowering sea, not always in positive terms, interacts with human beings as matter "is dynamic intra-active becoming that never sits still - an ongoing reconfiguring that exceeds any linear conception of dynamics in which affect follows cause end-on-end, and in which the global is a straightforward emanation outward of the local" (Barad, 2007: 170). In this instance, the sea emerges as a means of living while unpredictable conditions cost the peasants' lives. In this context, ontological presence of the sea is at the forefront of the action considering that physical force of the water is deeply felt through Maurya's sons in the sea.

Interestingly enough, it has to be recognised that agency of the sea cannot be restricted to its physical formations in Riders to the Sea. This is to say that the connection between the sea and people can be traced in another way. To specify, it is possible to explore narrative agency of matter through Maurya's vision on the sea. After Bartley leaves without his mother's blessing, the girls, Cathleen and Nora, persuade Maurya to go to the sea and give the bread to Bartley as he forgets to take. When Maurya returns, she appears disturbed and describes her vision to her daughters:

I went down to the spring well, and I stood there saying a prayer to myself. Then Bartley came along, and he riding on the red mare within the gray pony behind him. [She puts up her hands as if to hide something from her eyes] The Son of God spare us, Nora! [...] I'm after seeing him this day, and he riding and galloping. Bartley came first on the red mare; and I tried to say 'God bless you,' but something choked the words in my throat. He went by quickly; and 'the blessing of God on you,' says he, and I could say nothing. I looked up then, and I crying, at the gray pony, and there was Michael upon it - with fine clothes on him, and new shoes on his feet. (Synge, 1941: 185)

As reported by Mattar (2004), such a vision can be related to "the primitive spirit of Aran" (148). On the other hand, Davy (1996) claims that Maurya's vision evidences "the sea [as] a vehicle and a catalyst, a way of knowing" (41), and her 
acknowledgment of her sons' death from the vision on the sea suggests a metaphysical connection between the woman and the sea (Davy, 1996: 41). Kaya (2005), likewise, clarifies this obscure moment in that Maurya "undergoes a number of anomalous experiences pointing at her surprisingly spontaneous and powerful psychic abilities. Besides her inferential insight, she has a weird intuitive capacity for thinking about something before it happens and is able to see things invisible to the remaining characters" (164). She also pinpoints the metaphysical connection between the old mother and the sea as follows: "Due to her potential for an altered state of consciousness, Maurya sees visions of death in the sea to the effect that she can sense the radically divergent realms of the natural and the supernatural worlds" (Kaya, 2005: 166). More interestingly, however, such a supernatural moment can be deemed as Synge's "imaginative interaction with the material world" (Oppermann, 2012: 6). The playwright highlights the tie between human beings and agentic matter in a way that this vision can be associated with Barad's notion of agential realism with an emphasis on material and discursive competence of matter. This ability of matter enables to produce meanings so matter involves in an onto-epistemological realm. Bearing this in mind, the presence of matter in the context of the play is not restricted to its nature of existence, but the sea also comprises epistemological sphere. This amounts to saying that the narrative ability of the sea is unveiled in Maurya's vision. The agentic power of the sea is epitomised through her vision of death on the sea in which she becomes sure of her loss, justifying that "[a]ll forces and flows (materialities) are or can become lively, affective, and signalling" (Bennett, 2008: 117). From this vantage point, the interaction between the sea and Maurya is revealed owing to the narrative capability of matter. The sea both illustrates its own story and discloses the actuality of death for the islanders. Thus, Synge's sea appears to be "a storied matter" (Iovino and Oppermann, 2012a: 83) which becomes a text itself. In this regard, Maurya reads "the text" or recounts the story of the sea enmeshed with the story of her sons through her vision.

\section{CONCLUSION}

Broadly speaking, the sea has become a source of inspiration and a dominating element in various types of works of throughout the history. As a case in point, the presence of the sea is of utmost importance in heroic literature of ancient times as observed in Homer's Odyssey where the heroic figure goes through a journey in the sea and metamorphoses into an ideal and mature hero in this process. In Old English period, the sea plays a great role in the adventures depicted in Beowulf. In Romantic poetry, for instance, in Samuel Taylor Coleridge's (1772-1834) Rime of the Ancient Mariner (1798), the sea is the main setting in the mariner's tragic story where he is able to appreciate the power of nature in time. In another example by Matthew Arnold (1822-1888), the sea suggests the idea of separation and loss of religion and faith in 
“Dover Beach" (1867). Virginia Woolf's (1882-1941) The Waves (1931) is based on a relation between the movements of waves and the stories of different characters in a way that the stream of consciousness technique is embedded in this correlation. In Turkish literature, the names of Cevat Şakir Kabaağaçlı (1890-1973), or the Fisherman of Halicarnassus, and Sait Faik Abasıyanık (1906-1954) are to be recognised on the grounds that the sea is significantly used by both of the writers. Kabaağaçl1, for example, is claimed to offer a critical perspective about natural exploitation in his images of the sea (Saatçığlu, 2016: 581-600).

By virtue of the analysis of Synge's Riders to the Sea, agentic power of the sea alludes to another function as it becomes the focal point of the work since it dominates the life of the Irish peasants in two opposite ways as a source of survival/life and trauma/death. Although the title of the play alludes human endeavour to control the sea, its vigorous power is deeply felt by the islanders considering that their fates are shaped by its powerful presence. The play appears to reveal agentic capacity of matter and adds to its spectrum in its display of narrative ability of the sea. Therefore, the existence of the sea in this work can be highlighted within the arguments of new materialisms and material ecocriticism in that the sea becomes a kind of story teller in Synge's play and exposes its onto-epistemological dynamics. 


\section{WORKS CITED}

Alaimo, Stacy. Bodily Natures: Science, Environment, and the Material Self. Indiana: Indiana University Press, 2010.

Armstrong, W. A.Classic Irish Drama. Middlesex: Penguin, 1964.

Barad, Karen. Meeting the Universe Halfway. London: Duke University Press, 2007.

Bennett, Jane. Vibrant Matter: A Political Ecology of Things. Durham: Duke University Press, 2008.

Benson, E. J. M. Synge. Dublin: Macmillan, 1982.

Davy, Daniel. "Tragic Self-referral in Riders to the Sea."Assessing the Achievement of J. M. Synge. Ed. Alexander G. Gonzalez. London: Greenwood Press, 1996. 38-50.

Durbach, E. "Synge's Tragic Vision of the Old Mother and the Sea."Modern Drama 14.4 (1971): 363-372.

Fermor, U. E.The Irish Dramatic Movement. London: Methuen, 1967.

Frawley, O. "The shadow of the glen and Riders to the Sea."The Cambridge Companion to J.M. Synge. Ed. P. J. Mathews. Cambridge: Cambridge Press, 2009. 15-27.

Iovino, Serenella and Oppermann, Serpil. "Material Ecocriticism: Materiality, Agency, and Models of Narrativity.”Ecozon@ 3.1 (2012a): 75-91.

---."Theorizing Material Ecocriticism: ADiptych.”Interdisciplinary Studies in Literature 19.3 (2012b): 448-475.

Saatçığlu, Ece. "Halikarnas Balıkçısının Aganta Burina Burinata Romanını Ekoeleştirel Bakışla Okuma.” CBÜ Sosyal Bilimler Dergisi 14.1 (2016): 581-600.

Kaya, Şebnem."John Millington Synge's Riders to the Sea in terms of Epistemology." Hacettepe Üniversitesi Edebiyat Fakültesi Dergisi 22.1 (2005): 155-168. 
Mattar, S.G. Primitivism, Science, and the Irish Revival. Oxford: Oxford University Press, 2004.

O’Neill, J. K.“'Sympathy between man and nature': Landscape and Loss in Synge's Riders to the Sea."Out of Earth: Ecocritical Reading of Irish Texts. Ed. Christine Cusick. Cork: Cork University Press, 2010. 36-49.

Oppermann, Serpil."Material Ecocriticism and the Creativity of Storied Matter.”Frame 26.2 (2013): 55-69.

---."Rethinking Ecocriticism in an Ecological Postmodern Framework: Mingled Matter, Meaning, and Agency."Literature, Ecology, Ethics. Eds.Timo Müller and Michael Sauter. Heidelberg: Universitatverlag Winter, 2012. 5-20.

---."The Rhizomatic Trajectory of Ecocriticism.”Ecozon@ 1.1 (2010): 17-21.

"Sea." A Dictionary of Symbols. Ed. Jean Chevalier and Alain Gheerbrant. Trans. John Buchanan-Brown. London: Penguin, 1996.

Synge, John Millington. (1941). Riders to the Sea. Five Great Modern Irish Plays. Ed. George Jean Nathan. New York: The Modern Library, 1941. 174-189.

Synge, John. Millington.The Aran Islands. London: Penguin, 1992. 